\title{
A Preliminary Account of the Diatom Flora of Koria, Chhattisgarh
}

\author{
R. Sirmour*, M.L. Naik ${ }^{1}$ and M.P. Goutam ${ }^{2}$ \\ State Forensic Science Laboratory, Raipur, Chhattisgarh \\ ${ }^{1}$ Farm Forestry and Biotechnology, Surguja University, Surguja, Chhattisgarh \\ ${ }^{2}$ Department of Forensic Science, Guru Ghasidas Vishwavidyalaya, Bilaspur, Chhattisgarh \\ *E-mail: ravindrasirmour@gmail.com
}

\begin{abstract}
Water bodies contain a large number of microorganisms, like bacteria, algae, protozoa etc. Algae are the one of the very important group of the organisms. Diatoms are the well known water planktons belonging to family Bacillariophyceae (Hendy, 1980). Diatom flora of koria was observed by using acid digestion method. The present account is based on the collection of about 5 water samples from different place of koria. 18 species from 11 genera were identified from these collection sites; the genera include Achnanthes, Amphora, Cymbella, Eunotia, Fragilaria, Gomphonema, Hantizschia, Navicula, Nitzschia, Stauroneis and Synedra.
\end{abstract}

Key words: Algae, Diatom, Koria, Forensic significance.

\section{Introduction}

Freshwater is rich and dynamic medium for all microorganisms; Diatoms are one of the dominant groups present in water. Most of the water bodies like ponds, lakes, canals and river sustain diatoms. The beautiful structures of diatoms are complex, because of the presence of a silicious cell wall which resists acid digestion and heat. Diatoms have a constant shape and size, used as taxonomic characteristic. Every water body has its own diatom diversity; so far, there are no records of the diatoms flora from Koria District of Chhattisgarh State.

Koria is one of the North-West District of Chhattisgarh State. The District is bounded on the north by Shidhi District of Madhya Pradesh on the south Bilaspur Districts on the east by its parent District Surguja and on the west by Shahdol District of Madhya Pradesh. But so, far there are no records of the diatoms from Koria in Chhattisgarh State. Hence it was thought worthwhile to study the diatoms of this region. Koria District is located on the latitude Between $23^{\circ} 04^{\prime} 42^{\prime \prime}$ to $23^{\circ} 44^{\prime} 46^{\prime \prime}$ north and longitude Between $81^{\circ} 46^{\prime} 42^{\prime \prime}$ To $82^{\circ} 33^{\prime} 43^{\prime \prime}$ east of the Chhattisgarh State. It is 700 meters above the mean sea level. The average rainfall is about $1410.9 \mathrm{~mm}$. The minimum and maximum temperatures are $17^{\circ} \mathrm{C}$ and $32^{\circ} \mathrm{C}$, respectively.

\section{Materials and methods}

The water samples each were $100 \mathrm{ml}$ collected from various ditches, pools, ponds and river. The collected water samples were preserved in $4 \%$ formalin. $85 \mathrm{ml}$ of each water sample was decanted off; retaining $15 \mathrm{ml}$ of sample including the sediment were centrifuged for $5 \mathrm{~min}$. at $5000 \mathrm{rpm}$. Settled 
R. Sirmour, M.L. Naik and M.P. Goutam / Our Nature (2012) 10: 199-205

part of the sample were mixed with concentrated acids in the ratio of $\left(\mathrm{HNO}_{3}+\right.$ $\mathrm{HCl} ; 3: 1)$ and digested over hot plate for 3-4 hour's and allow to cool. After digestion the dried diatoms were diluted with distilled water. Observation make trinocular microscope (Leica) and diagram were drawn with the help of micrometer scale.

Diatoms were identified with the help of available literature including Heurck (1869), Gandhi (1959), Sarode and Kamat (1980), Suxena (1998), and Sirmour (2009).

\section{Observations and results}

In the present communication, only 18 fresh water diatoms species belong with 11 different genera have been described (Pl. 1, Tab. 1).

Achnanthes sp. Bory. (Fig. 1)

Valve $8 \mu \mathrm{m}$ long, $2-4 \mu \mathrm{m}$ broad. Cells are heterovalvar and are flexed in girdle view.

\section{Amphora acutiuscula Kütz. (Fig. 2)}

Length $28-35 \mu \mathrm{m}$, breadth 5-6 $\mu \mathrm{m}$ and striae $14-16$ in $10 \mu \mathrm{m}$, and on the ventral side very fine and marginal.

Amphora coffeoeformis Agardh var. africana Fritsch and Rich. (Fig. 3)

Valves 21-25 $\mu \mathrm{m}$ long, 4-7 $\mu \mathrm{m}$ broad, striae 20-23 in $10 \mu \mathrm{m}$.

Cymbella sp. Kütz. (Fig. 4)

Valve $26 \mu \mathrm{m}$ long, $7 \mu \mathrm{m}$ broad, asymmetrical, raphe arcuate, striae 12-14 in $10 \mu \mathrm{m}$

Eunotia major (W.Smith) var. indica (Grun.) A. Bg. (Fig. 5)
Valves 32-39 $\mu \mathrm{m}$ long, 7-10 $\mu \mathrm{m}$ broad, sublinear, arcuate with ventral side concave and dorsal side convex. striae 15-17 in $10 \mu \mathrm{m}$ at the ends.

Fragilaria capucina Desm. (Fig. 6)

Valves 28-35 $\mu \mathrm{m}$ long, 2.9-3.5 $\mu \mathrm{m}$ broad, slender, sublinear, narrow towards the ends, ends slightly constricted, pseudoraphe distinct, liner-lanceolate, striae $16-18$ in $10 \mu \mathrm{m}$.

\section{Fragilaria capucina var mesolepta} (Rabenhorst) (Fig. 7)

Valve linear to linear lanceolate, constricted at the central area. Valves 10-100 $\mu \mathrm{m}$ long, 2-6.5 $\mu \mathrm{m}$ broad, striae $15-18$ in $10 \mu \mathrm{m}$.

Gomphonema angur Ehr. (1840) (Fig. 8)

Valves obviously asymmetrical to transapical axis (heteropolar), symmetrical to apical axis. The head pole usually much wider that tail. Cells wedge-shaped in girdle view with pseudosepta visible. Apices rostrate to capitate. Raphe often slightly sinuous. Vales 13-130 $\mu \mathrm{m}$ long, 4-20 $\mu \mathrm{m}$ broad, straie 7- 18 in $10 \mu \mathrm{m}$.

Gomphonema constrictum var. indica var. nov (Fig. 9)

Valves $30-45 \mu \mathrm{m}$ long, $10-12 \mu \mathrm{m}$ broad clavate, apex constricted broadly produced and rounded. striae about12-15 in $10 \mu \mathrm{m}$. radical and clearly punctuate.

Hantizschia amphioxys (Ehr.) Grun. (Fig. 10)

Cells solitary Frustules isopolar but dorsiventral. Cells lie in valve or girdle view, those in girdle view being rectangular because the valve faces are flat and parallel. 
Valves bilaterally asymmetrical (dorsiventral), with a slightly concave ventral margin and a convex dorsal margin. Poles rostrate or capitate, rarely (small cells only) simply rounded. Transverse striae visible regularly spaced, sometimes visibly uniseriate. Keel very excentric, keel punctuate coarse. Valves 20-210 $\mu \mathrm{m}$ long, $4-15 \mu \mathrm{m}$ broad, striae $11-28$ in $10 \mu \mathrm{m}$.

Navicula cuspidate Kütz. f. brevirostrate f. nov. (Fig. 11)

Valves 18-27 $\mu \mathrm{m}$ long, 5-7 $\mu \mathrm{m}$ broad, lanceolated with rounded ends. Raphe thin and straight. Axial area very narrow.

Navicula dicephala (Ehr.) Smith var. elginensis (Greg.) Cl. (Fig. 12)

Valves 20-45 $\mu \mathrm{m}$ long, 7-11 $\mu \mathrm{m}$ broad, transverse striations slightly radical, striae $10-12$ in $10 \mu \mathrm{m}$.

Navicula lanceolata (Agardh) Kütz. var. tenella A.S. (Fig. 13)

Valves 2-28 $\mu \mathrm{m}$ long, 4-6 $\mu \mathrm{m}$ broad, and striae $14-16$ in $10 \mu \mathrm{m}$

Navicula sp. Bory. (Fig. 14)

Valves $8 \mu \mathrm{m}$ long, $2 \mu \mathrm{m}$ broad.

Nitzschia sigma W. Sm. var. rigidula (Fig. 15)

Valves gently sigmoid, ends attenuate narrow, length 35-60 $\mu \mathrm{m}$ long, 4-5 $\mu \mathrm{m}$ broad, carinal dots 4-14 in $10 \mu \mathrm{m}$.

Stauroneis phaenicenteron Ehr. f. capitata forma nova (Fig. 16)

Valves narrowly lanceolate and delicate, with large, rounded, capitate end. Raphe thick, with bifurcated terminal fissure. valves $70-113 \mu \mathrm{m}$ long, $14-21 \mu \mathrm{m}$ broad, axial area fairly wide, central area stauroid, slightly dilated towards the sides, striae fine but distinctly punctuate and strongly radial, striae $18-21$ in $10 \mu \mathrm{m}$.

\section{Synedra acus Kütz. (Fig. 17)}

Valves $85-102 \mu \mathrm{m}$ long, 4-5 $\mu \mathrm{m}$ broad in the middle, striae fine, $12-15$ in $10 \mu \mathrm{m}$.

Synedra sp. Ehr. (Fig. 18)

Valves $104 \mu \mathrm{m}$ long, $4-6 \mu \mathrm{m}$ broad, striae $12-20$ in $10 \mu \mathrm{m}$.

\section{Conclusion with forensic importance}

Forensic science is an area of applied science that uses physical evidence to piece together the events that occurred at suspected crime scenes. Forensic botany is defined as the use of plant evidence in court. Forensic botany is subdivided into several botanical subspecialties, including plant anatomy, plant systematic, palynology, plant ecology and limnology (the study of freshwater ecology) was suggested by Vaughn et al. (2006). Quatrehomme et al. (1997) said that freshwater ecology or limnology can be applied to a subset of forensic cases.

When a person drowns in freshwater, diatoms are taken in along with water into the lungs. The diatoms are dispersed to the internal organs of the body. The diatom test is performed by extraction of bone marrow from an intact femur, heating the marrow in a nitric acid solution and centrifuging to pellet the solids (Coyle et al., 2001). The solids are examined on slides by microscopy for the presence of diatom species.

In particular, aquatic plants like algae and diatoms have been useful to link 
R. Sirmour, M.L. Naik and M.P. Goutam / Our Nature (2012) 10: 199-205
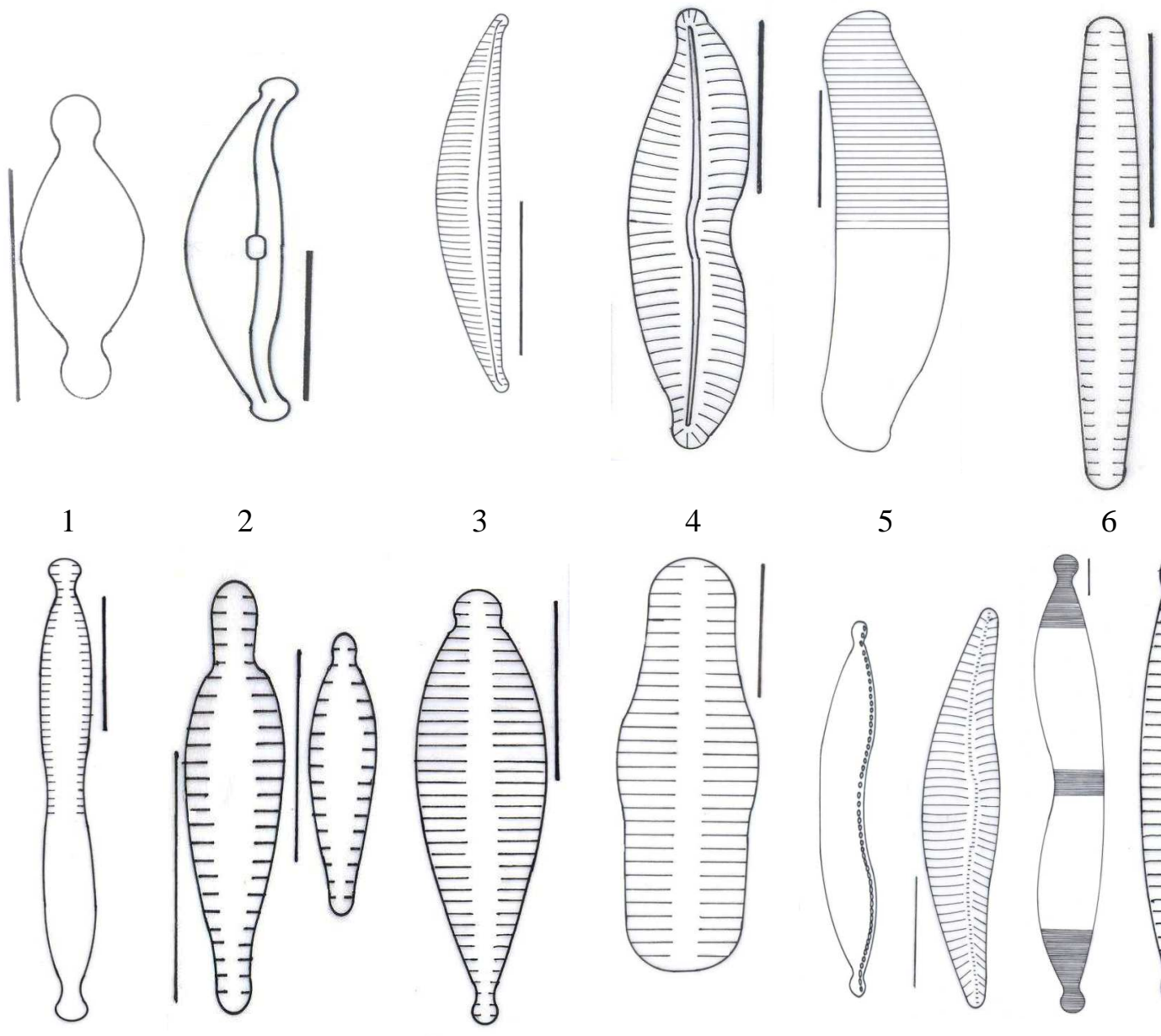

2
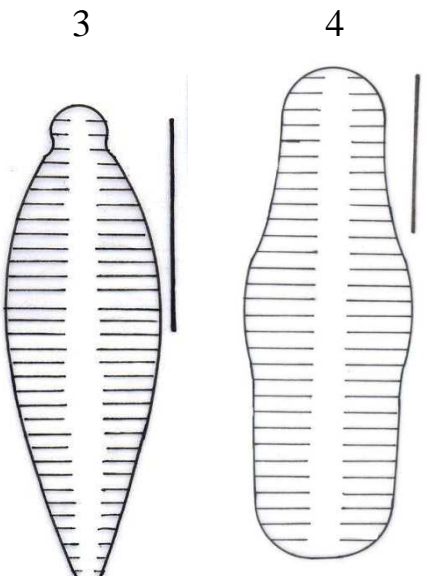

5

6

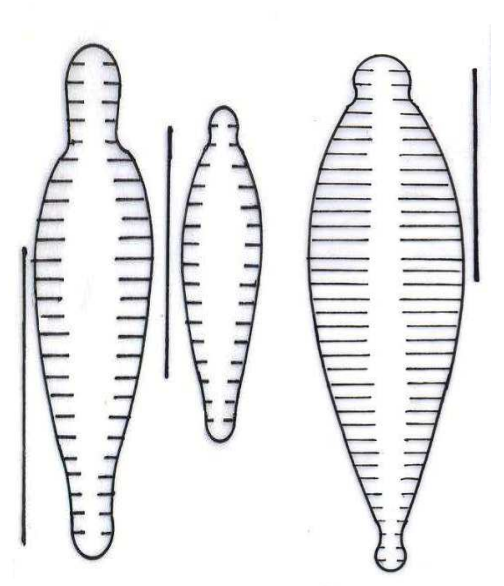

8

9
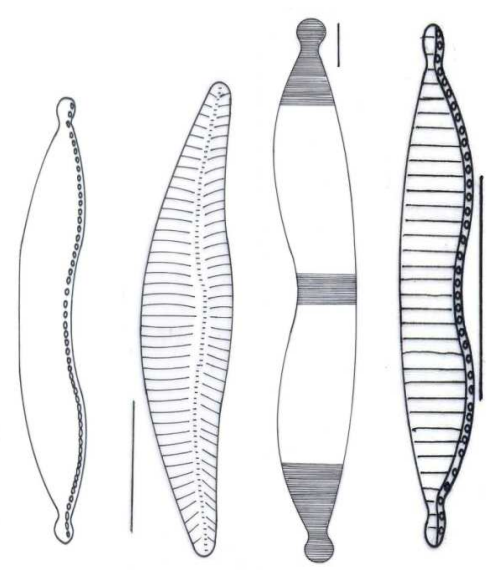

10 
R. Sirmour, M.L. Naik and M.P. Goutam / Our Nature (2012) 10: 199-205
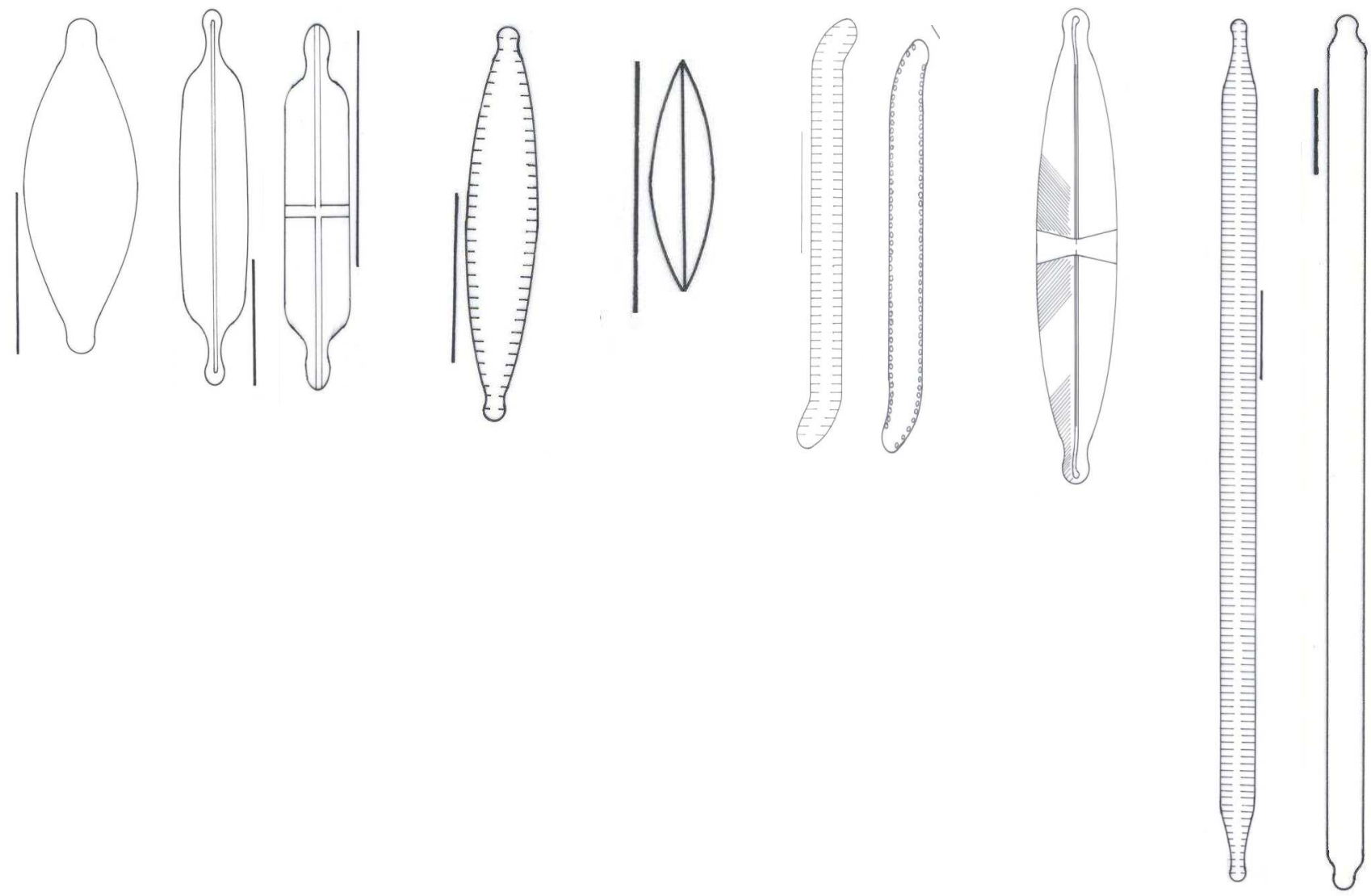

11

Plate 1. Figures 1. Achnanthes sp., 2. Amphora acutiuscula, 3. Amphora coffeoeformis var. Africana, 4. Cymbella sp., 5. Eunotia major var. indica, 6. Fragilaria capucina, 7. Fragilaria capucina var mesolepta, 8. Gomphonema angur, 9. Gomphonema constrictum var. indica, 10. Hantizschia amphioxys, 11. Navicula cuspidate f. brevirostrate, 12. Navicula dicephala var. elginensis, 13. Navicula lanceolata var. tenella, 14. Navicula sp., 15. Nitzschia sigma var. rigidula, 16. Stauroneis phaenicenteron f. capitata, 17. Synedra acus, 18. Synedra sp. 
Table 1. Genera identified from different sites.

\begin{tabular}{|c|c|c|c|c|c|}
\hline \multirow{2}{*}{ Name of the species } & \multicolumn{5}{|c|}{ Sites of collection } \\
\hline & $\mathrm{a}$ & $\mathrm{b}$ & $\mathrm{c}$ & $\mathrm{d}$ & e \\
\hline Achnanthes sp. Bory. & - & - & - & - & + \\
\hline Amphora acutiuscula Kütz. & + & - & - & - & - \\
\hline Amphora coffeoeformis Agardh var. africana Fritsch and Rich. & + & - & - & - & - \\
\hline Cymbella sp. Kütz. & - & + & - & - & - \\
\hline Eunotia major (W. Smith) var. indica (Grun.) A. Bg. & + & - & - & - & - \\
\hline Fragilaria capucina Desm. & - & - & - & + & 一 \\
\hline Fragilaria capucina var mesolepta (Rabenhorst) & - & - & - & - & + \\
\hline Gomphonema angur Ehr.(1840) & - & + & - & - & - \\
\hline Gomphonema constrictum var. indica var. nov & - & + & - & - & - \\
\hline Hantizschia amphioxys (Ehr.) Grun. (1877) & + & - & 一 & - & 一 \\
\hline Navicula cuspidate Kütz. f. brevirostrate f. nov. & 一 & - & + & - & - \\
\hline Navicula dicephala (Ehr.) Smith var. elginensis (Greg.) Cl. & - & - & + & - & - \\
\hline Navicula lanceolata (Agardh) Kütz. var. tenella A.S. & + & - & - & - & 一 \\
\hline Navicula sp. Bory. & - & - & + & - & - \\
\hline Nitzschia sigma W. Sm. var. rigidula & 一 & - & + & 一 & - \\
\hline Stauroneis phaenicenteron Ehr. f. capitata forma nova & 一 & + & 一 & 一 & - \\
\hline Synedra acus Kütz. & 一 & - & + & 一 & 一 \\
\hline Synedra sp. Ehr. & - & + & - & - & - \\
\hline
\end{tabular}

$\mathrm{a}=$ Jamnahama Pond, $\mathrm{b}=$ Gaj River, $\mathrm{c}=$ Near arrigation Colony Pond, d = Near mandir Pond, e = Near Jail Pond

suspects to a crime scene or to establish that drowning occurred in freshwater. There are no works on diatom taxonomy of the Koria District. Present study has highlighted the occurrence and distribution of diatom flora in the study area.

\section{Acknowledgements}

The authors are thankful to the Head, SOS in Life Sciences, Pt. Ravishankar Shukla University, Raipur, for providing necessary facilities to carry out these work.

\section{References}

Coyle, H.M., C. Ladd, T. Palmbach and H.C. Lee 2001. The green revolution: Botanical contributions to forensics and drug enforcement. Croatian Medical Journal 42(3): 340-345.

Gandhi, H.P. 1959. Fresh water diatoms from Sagar in the Mysore state. J. Ind. Bot. Soc. 38(3): 305-331.

Heurck, H. 1869. A treatise on the diatomaceae. Translated by W.E. Baxter, William Wesley and Sons., London. 558p.

Quatrehomme, G., A. Lacoste, P. Bailet, G. Grevin and A. Ollier 1997. Contribution of microscopic plant anatomy to postmortem bone dating. $J$. Forensic Sci. 42: 140-3. 
R. Sirmour, M.L. Naik and M.P. Goutam / Our Nature (2012) 10: 199-205

Sarode, P.T. and N.D. Kamat 1980. The diatoms flora of Nagpur, India. Nova Hedwingia 32: 797-838.

Sirmour, R. 2009. Study of diatoms of water bodies of Chhattisgarh region and its forensic significance. Pt. Ravishankar Shukla University, Raipur. Ph.D. Thesis.

Suxena, M.R. 1998. A taxonomic and systemic survey of the diatoms taxa and their synonyms, described from India and it's adjoining countries (excluding marine and fossil species), $1^{\text {st }}$ Ed., Department of Botany, Osmania University, Hyderabad, India.

Vaughn, M., A. Bryant, D. Gretchen and B. Jones 2006. Forensic palynology: Current status of a rarely used technique in the United States of America. Forensic Science International 163: 183-197. 